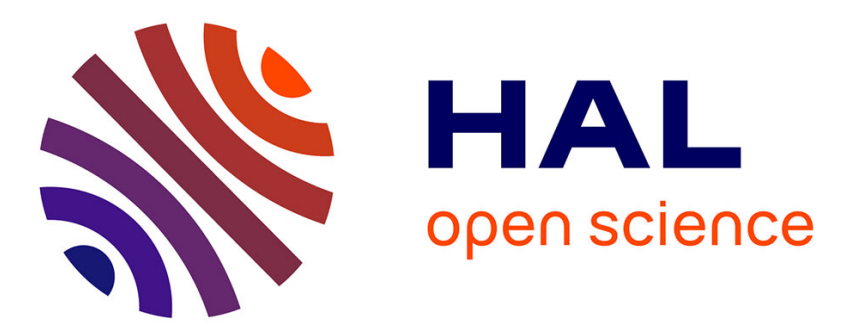

\title{
First experiences with reading primary literature by undergraduate life science students
}

Edwin van Lacum, Miriam Ossevoort, Hendrik Buikema, Martin Goedhart

\section{To cite this version:}

Edwin van Lacum, Miriam Ossevoort, Hendrik Buikema, Martin Goedhart. First experiences with reading primary literature by undergraduate life science students. International Journal of Science Education, 2011, pp.1. 10.1080/09500693.2011.582654 . hal-00719478

\section{HAL Id: hal-00719478 https://hal.science/hal-00719478}

Submitted on 20 Jul 2012

HAL is a multi-disciplinary open access archive for the deposit and dissemination of scientific research documents, whether they are published or not. The documents may come from teaching and research institutions in France or abroad, or from public or private research centers.
L'archive ouverte pluridisciplinaire HAL, est destinée au dépôt et à la diffusion de documents scientifiques de niveau recherche, publiés ou non, émanant des établissements d'enseignement et de recherche français ou étrangers, des laboratoires publics ou privés. 



First experiences with reading primary literature by undergraduate life science students

\begin{tabular}{|r|l|}
\hline Journal: & International Journal of Science Education \\
\hline Manuscript ID: & TSED-2010-0482-A.R1 \\
\hline Manuscript Type: & Research Paper \\
\hline Keywords: & argumentation, biology education, scientific literacy \\
\hline Keywords (user): & genre analysis, primary literature, higher education \\
\hline \multicolumn{2}{|l}{} \\
\hline
\end{tabular}

\section{SCHOLARONE ${ }^{\text {Th }}$ \\ Manuscripts}




\begin{abstract}
Learning to read and understand research articles (primary literature) is an important step in the enculturation of higher education students into the scientific community. We presume, based on ideas from the field of genre analysis, that it is important for the development of reading skills to become conscious of the rhetorical structures in research articles. So, we determined how well science students are able to identify two important elements of this rhetorical structure: conclusions and grounds. First-year undergraduate life science students who followed a course called 'Biomedical Research' made assignments in which they had to identify these two elements. We analysed the answers of 20 students in detail and compared their answers with two expert readers. Furthermore, we conducted task-based interviews with four students to gain more insight in their reading strategies and to determine how they identify conclusions and grounds. Our results show that students and experts defined conclusions and grounds in different ways. Students and experts agreed on the most important conclusion of the articles. However, students identified a wide range of sentences which were not seen as conclusions by the experts. The grounds students mentioned mostly matched with their conclusions. Students sometimes failed to mention important grounds for a particular conclusion. In conclusion, our study shows the differences between student and expert readers of primary literature. Based on our results, we formulated criteria for the design of a teaching strategy that aims to improve students' skills for reading primary literature.
\end{abstract}

Keywords: argumentation, biology education, genre analysis, higher education, primary literature, rhetorical moves, science reading 


\section{Introduction}

The research article, the most common type of primary literature, plays a pivotal role in the communication of scientific ideas. Due to the internet and electronic databases, scientists have nowadays easy access to a rapidly growing amount of research papers. Consequently, this has influenced their reading habits. Surveys indicate that the average number of article readings per scientist has increased. In 1993, scientists read on average 188 articles per year. In 2005, this number rose to 280 articles per year (Tenopir, 2009). However, the total time spent on reading primary literature has only increased marginally. Therefore, it is more important than ever for scientists to develop skills that will enable them to read research papers in an efficient way.

Holliday, Yore, and Alvermann (1994) have compared science reading with science learning:

Both science reading and science learning can be described as an interaction between prior knowledge, concurrent experience, and information accessed from print and other sources in a specific social context that is focused on constructing meaning. Readers interactively process information by switching between selective perceptions of textbased information (print, charts, pictures) and concurrent experiences (concrete inquiries, discussions, thinking) and comparison of the information and experiences with their personal knowledge (topic, domain, scientific enterprise, textual, strategic (p. 879).

Therefore, readers need specific skills for understanding science texts. Learning the language of science is an important step in the enculturation of students into the scientific community. However, mastering the complex skill of reading and understanding research papers is not easy for the novice reader.

Fang (2005) describes a number of characteristics of the language of scientific text 
(research papers or textbooks) which can cause reading difficulties with inexperienced readers. Firstly, scientific writing has a high density of information. Sentences often contain a high number of nouns and extended noun phrases. This is an efficient way of communication, but it also may lead to confusion, because the syntactic clues which specify the semantic relationships between the nouns are left out (Gross, Harmon, \& Reidy, 2002). Secondly, scientific writing is often abstract. Concrete experiences are turned into abstract entities via the conversion of verbs and adjectives into nouns. For example: 'wheeze and become short of breath' are synthesised into 'asthma attacks'. This process, called nominalization, can 'create problems for readers, because it tends to neutralize or obscure meanings and construct an ideology that is often not transparent to naïve readers' (Fang, 2005, p. 340). Thirdly, scientific texts contain a high number of technical terms. Students who are not familiar with these specialised terms will struggle with comprehending the text. Fourthly, scientific writing is authoritative. Authors try to distance themselves from the text, e.g. by avoiding first person references. This can alienate students, who are often used to more personal and informal texts.

In addition, students are mostly used to textbooks, which 'are written mainly to deliver agreed-upon, objective facts to a student audience. The main task for readers is to understand straightforward factual statements' (Gillen, 2006, p. 34). In contrast, research articles are persuasive (or argumentative) by nature (Gillen, 2006; Yarden, 2010). Experimental data is used to convince other readers that the presented conclusions are justified. This process of persuasion plays an important role in science: scientists are constantly justifying their claims (and attacking counterclaims) in papers, on conferences, during lab talks, and so forth. The claims forwarded by scientists do not speak for themselves; acceptance in the scientific community is strongly dependent on the used rhetorical means. For example, authors of research articles use often so- 
called hedges: words like 'may', 'might' or 'possibly', which indicate the uncertainty of statements. As Hyland (1998) remarks:

Hedges are a crucial means of presenting new claims for ratification and are among the primary features which shape the research article as the principle vehicle for new knowledge. Hedging enables writers to express a perspective on their statements, to present unproven claims with caution and to enter into a dialogue with their audiences (p. 6).

To fully understand a research article, one must have a firm grasp of these intricate semiotic constructions. Therefore, it is important that students in higher education who aspire to be scientists, learn how to read research articles. Furthermore, understanding how research articles are organized can give students more insight into scientific argumentation. Argumentation should be an integral part of science education (Jiménez-Aleixandre \& Erduran, 2008) and reading research papers could contribute to achieve this aim. However, developing students' reading skills is a great challenge for educators, due to the beforementioned characteristics of research articles.

\section{Literature review}

\section{Reading strategies of scientists and science students}

Bazerman (1988) has probably published the most extensive study on the reading strategies of scientists. He interviewed seven physicists about their reading strategies and observed four of them while reading articles. Bazerman found that the physicists read articles selectively (reading not all parts of an article). Often they skip whole parts of the text, only reading the newsworthy parts. What was considered the news depended on the interests and purposes of the scientist. For instance, if the reader was very familiar with the topic of the article, he tended to skip most of the 
text and only stopped at new techniques, tricks or equations. Furthermore, the physicists read articles non-sequentially (not reading the parts of an article in order). They often read backwards and jumped back and forth (when, for example, a certain section raised questions about an earlier one). These results were confirmed in a similar study by Berkenkotter and Huckin (1995).

Additionally, Bazerman (1988) describes that scientists may read articles with two different purposes. If they only want to extend their background knowledge, they tend to read less critically. On the other hand, if they want to mobilise parts of the article for their own work, they read in a much more critical way. They are, in other words, evaluating the article. Bazerman describes how this takes place. For example, when trying to determine the reliability of an article, scientists looked at the internal evidence and the style.

According to Bazerman (1988), the reading strategies of scientists are very much dependent on what he calls the 'purpose-laden schema'. This is a 'personal map' of the field, which 'provides the framework against which the reader comes to understand an article. The reader will process information that has significance for the existing schema and will view that information from the perspective of the schema' (p. 243). So, the purpose-laden schema will influence how readers approach an article. Bazerman's results correspond with a study by Charney (1993), whose research suggests that scientists read articles rhetorically: '.. they read as is convenient for their own purposes (they read parts selectively and out of order); they weigh the plausibility of claims and evidence; they struggle to understand unfamiliar technical terms; they cheer and get mad' (p. 228). Furthermore, Charney found that graduate students tended to do no more than understanding the text and integrate it with their prior knowledge. Brill, Falk, and Yarden (2004) describe how novice readers (in this case high school biology students) try to comprehend an adapted research article. They observed that students encountered a number of 
comprehension difficulties, probably due to a lack of schemas and automation (which expert readers do possess). For example, one of their students was not able to create a coherent understanding of the text when reading the Abstract. This is in contrast to expert readers, the authors surmised: 'Expert readers can apply preformed schemas to construct the main outline of the research that is about to be read from the abstract, although they have never read about it before' (p. 508).

Although these studies provide us with some insight into the reading strategies of scientists and to a lesser extent of high school and graduate students, they contain almost no information about how we can teach students to read primary literature in an effective way.

There are a number of interesting hands-on studies available on the use of primary literature in colleges and universities (Jacques-Fricke, Hubert, \& Miller, 2009; Janick-Buckner, 1997; Kuldell, 2003; Levine, 2001; Mulnix, 2003; Peck, 2004) but these are rather vague about the reading skills of students. For example, students are asked in these studies if they feel that they have become better readers. However, their changed perception does not necessarily mean that their actual reading skills have been improved. So, there is a gap in knowledge regarding the development of reading skills among students.

\section{Genre analysis}

One possible and promising method to improve reading skills could be to increase the students' understanding of the genre conventions of the scientific research article. Swales (1990) defines genre as follows:

Comment [EVL7]: Removed an unnecessary question: "How can students turned into better readers of primary literature?"

A genre comprises a class of communicative events, the members of which share some set of communicative purposes. These purposes are recognized by the expert members of 
the parent discourse community and thereby constitute the rationale for the genre. This rationale shapes the schematic structure of the discourse and influences and constrains choice of content and style (p. 58).

Swales (1990) argues that for the development of reading and writing skills it is important for novice readers to become conscious of the rhetorical effects and structures of genre-specific texts; they need to develop a rhetorical consciousness. Other authors have made the same point as Swales (e.g. Cook \& Meyer, 1988; Hill, Soppelsa, \& West, 1982) although it has to be noted that some authors are rather critical of this so-called 'genreist' approach. These opponents argue that students should not be coerced into using stilted forms of text (for an overview of this discussion, see Purcell-Gates, Duke, \& Martineau, 2007).

The rhetorical structure of research articles can be described by analysing the rhetorical moves in a text (Swales, 1990). A rhetorical move refers 'to a section of a text that performs a specific commmunicative function. Each move not only has its own purpose but also contributes to the overall communicative purposes of the genre' (Connor, Upton, \& Kanoksilapatham, 2007, p. 23). Swales himself has done some influential research on this subject. He analysed the Introduction sections of research articles and discovered that they contain often the same moves (Swales, 1981). Later on, he revised this model into CARS (Creating A Research Space), a 3 step-model which distinguishes the following three moves: Establishing a territory (e.g. reviewing previous research), Establishing a niche (e.g. indicating a gap in knowledge), and Occupying the niche (e.g. outlining the study's purpose) (Swales, 1990).

Probably due to their straightforward nature, genre analysts have not looked in great detail at the Method section (with the exception of Kanoksilapatham, 2005). However, the Results and Discussion sections were studied quite extensively. The rhetorical moves of the Results section 
(described by Brett, 1994; Kanoksilapatham, 2005; Thompson, 1993; Williams, 1999) can be subdivided into two groups: presentational moves (i.e. data descriptions) and comment moves (i.e. interpretations, explanations, comparisons). Dudley-Evans (1994), Peacock (2002), and Kanoksilapatham (2005) have analysed the Discussion section. The former designated the evaluation of results as the main part of the Discussion section and identified the following moves in it:

1) Information move: background information about theory, research aim, methodology, or previous research.

2) Statement of result: presents a numerical value or refers to a graph or table.

3) Finding: observation arising from research; contains no reference to a graph or table.

4) (Un)expected outcome: comment on an expected or unexpected/surprising result.

5) Reference to previous research: used to compare results or as support for claim.

6) Explanation: reasons for an unexpected result.

7) Claim: a generalisation arising from the results.

8) Limitation: caveats about the findings, methodology or claims.

9) Recommendation: suggestions for future lines of research or methodology.

Gross et al. (2002) characterized science as follows: 'To do science is to assert that a fact or a theory is true of the natural world and to defend that assertion' (p. 187). That is why we consider assertions and the evidence authors use to defend them, as the two central elements of a research article to which we are limiting our research. We call -following Day (1998)- the assertions in a reseach paper conclusions (although you may also call them claims or knowledge claims), which correspond with Dudley-Evans' (1994) move 7. So, conclusions are generalisations arising from the results. We call -following Toulmin, Rieke, and Janik (1979)- 
the evidence in a research paper grounds, which correspond with Dudley-Evans' (1994) moves

2, 3, and 5. The grounds described by Dudley-Evans (1994) are not exclusive to the Discussion; for example, findings and statements of result can also be found in the Results section.

\section{Aim}

In this paper we describe to which extent undergraduate students are able to identify rhetorical moves in research articles and compare their abilities with expert readers. Our subjects were first-year life science students who followed a course at the [name of institute] called 'Biomedical Research'. One of the main features of this course is the focus on reading primary literature. We decided to monitor the course and develop assignments, so we could get a clearer picture of the undergraduate students' rhetorical consciousness regarding primary literature. Furthermore, we compared students' performances with expert readers. The reading skills of these expert readers indicated to us the level which students ultimately should reach in their academic career.

So, our research questions were:

1) Which types of statements in a research article do undergraduate life science students identify as conclusions and grounds and do these statements correspond with the statements found by expert readers?

2) Which textual features do undergraduate life science students use to identify conclusions and grounds and do these features correspond with experts?

3) What kinds of reading strategies do undergraduate life science students use when they read an research article and identify conclusions and grounds?

With the answers of these research questions, we want to formulate criteria which can be

used to design a teaching strategy that aims to improve students' skills for reading primary

Comment [EVL14]: Defined in a more precise way the terms 'conclusion' and 'ground'. Furthermore, we moved this section from the Aim to Genre Analysis.

Comment [EVL15]: Rephrased research aim. 
literature.

\section{Method}

\section{Educational setting}

The data collection took place during a 10-week course called 'Biomedical Research', which is part of the last quarter of the first-year program of bachelor life sciences at the [name of institute]. The subjects of the course were related to physiology and pharmacology, in particular the cardiovascular system. The course consisted of lectures, lab work, and tutor-led meetings.

\section{Participants}

The total number of participants which entered the course was 138. For the tutor-led meetings, all students were randomly divided in twelve groups. The tutors were senior medicine students and life science students. For our data collection, we randomly chose two tutor groups, consisting of nine and eleven first-year students. Eight students were male and twelve students were female. They were 18 or 19 years old. All students were novice readers of primary literature and their native language was [language]. At the beginning of the course, these students (minus one) filled out a questionnaire about their reading experiences regarding primary literature. The majority of the students (thirteen) said they had read four to six research articles in previous courses. Three students had read less than four articles and three students had read more (up to seven-twelve articles).

The two experts (called Expert A and Expert B) were a professor and an assistant professor who both were lecturers of the course. They both frequently write research articles and are Comment [EVL19]: Replaced 'panel of experts' with 'two experts' experienced readers of primary literature in the area of cardiovascular research. 


\section{Intervention}

Assignments. In this study we present the written answers to the three assignments of the abovementioned 20 students. These assignments were given in weeks 3,4 , and 5 of the course as homework and consisted of individually reading a research article and answering questions about the conclusions and grounds in the article. In each week a different research article was used.

The concepts presented in the articles had been discussed during lectures beforehand. The assignments, including the articles, were handed out and explained by the tutor at the end of each tutor meeting. Approximately six days later, the students handed in their answers via e-mail. In the following tutor-led meeting, the answers of the students on the assignments were discussed. The assignments were:

- Assignment 1 (Article 1): Write down verbatim the sentence or sentences that are according to you conclusions and point out which conclusion or conclusions is/are the most important.

- Assignment 2 (Article 2): Write down verbatim the sentence or sentences that are according to you conclusions and point out which conclusion or conclusions is/are the most important. Furthermore, write down verbatim the grounds of each conclusion.

- Assignment 3 (Article 3): Write down the sentence or sentences that are according to you conclusions and point out which conclusion or conclusions is/are the most important. Furthermore, write down the ground(s) of each conclusion. You are allowed to paraphrase the article's sentences.

(To make sure that students knew what we meant, we did not use the word 'ground', but the [language] translation of the word 'support'.) 
Research articles. The research articles were selected by the course instructors and remained in their original state. All three articles had the conventional Introduction, Method, Results, And Discussion (IMRAD) structure. Article 1 contained approximately 4000 words, one table, and two figures. Article 2 contained approximately 5000 words, six tables, and five figures. Article 3 contained approximately 6000 words, three tables, and six figures. Readability of the articles was measured using the Flesch Reading Ease Score (Flesch, 1948). This score puts texts on a scale between 0 (very difficult to read) and 100 (very easy to read). Article 1 had a Flesch Reading Ease score of 62, Article 2 of 27, and Article 3 of 47. This means that Article 1 had a 'standard' readability and that Articles 2 and 3 were, respectively, 'very difficult' and 'difficult' to read. Although the readability varied, all research articles satisfied the criteria set out by Muench (2000) for selecting suitable primary literature for novice readers: the experiments in the article could easily be visualised and the given results were unambiguous. Furthermore, the relationship between the conclusion and the data was relatively simple in all three articles. The three articles used subsequently for Assignments 1, 2, and 3 were:

1) Miranda et al. (2007), in which the authors established if the electrocardiogram (ECG, a recording of the electrical activity of the heart) and/or echocardiogram (ECHO, a moving ultrasound picture of the heart) are able to adequately predict the size of a myocardial infarction in rats.

2) Kleiger et al. (1987), in which the authors test the hypothesis that the degree of heart rate variability can predict long-term survival after a (acute) myocardial infarction.

3) Prunier et al. (2007), in which the authors determined if treatment with erythropoietin (EPO) has a positive influence on rats who suffered a myocardial infarction. Furthermore, we performed our own move analysis of the Results and Discussion sections 


\section{Data sources}

Assignments. All students' written answers were collected. In addition, the two experts made Assignments 1 and 3, and handed them in via e-mail.

Student interviews. Four students (Jessica, Bill, Mary, and Leah - fictitious names) were asked to make the assignments during a task-based interview (Goldin, 2000). The task-based interviews took place in a lecture room at the university, where the students had access to an internet-connected computer. Jessica and Bill were observed while making Assignment 1 and 3, Leah was observed while making Assignment 2 and Mary was observed while making Assignment 3. We provided them with paper versions of the research articles.

We asked the students to articulate their thoughts as much as possible while reading the articles and making the assignments. During this process we followed the guidelines of Van Someren (1994). In the semi-structured interview afterwards we asked them general questions about the article and assignment (What did you think of the article? Was it easy to read? What did you think of the assignment? What is a conclusion and how can you recognise it? etc.). In addition, we asked them to tell us how they came to their answers. These sessions were audiorecorded and transcribed verbatim. In addition, students' search history on the computer was registered. We timed how long it took to read the article and make the assignment.

Experts interview. The interview with the experts took place after the students and experts had handed in the written answers to their assignments. To prepare for the expert interview, we analysed the written answers of students and experts to the assignments. Then we interviewed 


\section{Data analysis}

Assignments. For the written answers' analysis, we chose the sentence as unit of analysis because, in our experience, sentences (in contrast to paragraphs) seldom contain more than one rhetorical move. For Assignments 1, 2, and 3, we determined how many sentences each student and expert identified as conclusion and in which section of the article (Abstract, Introduction, Method, Results or Discussion) they found them. We made a list of the sentences that were most frequently mentioned as the most important ('main') conclusion by the students. Reporting verbs and transition words/phrases were underlined (Thomas \& Hawes, 1994). Then, we compared the student results with the expert results. One student did not hand in Assignment 1. Two students did not hand in Assignment 2.

For assignments 2 and 3, we analysed the grounds students mentioned. We performed two different analyses. In the first analysis we grouped all students' grounds together and determined, based on the definitions by Dudley-Evans (1994), for each conclusion or set of conclusions if the grounds contained an (a) statement of result, (b) finding, (c) citation (i.e. reference to previous research), or (d) another conclusion (i.e. claim). We added one category to this list. Students could also refer to non-textual elements like (e) inscriptions (figures or tables). For this analysis, we used the answers of 17 students; three students did not hand in both assignments. In the 
second analysis we determined if students' grounds for three selected conclusions in each article (assigned by us or the experts as important) were correct (i.e. referred to matching data or data interpretations) and complete (i.e. referred to the most important data or data interpretations mentioned in the text). Correctness and completeness were determined by the experts' comments in the interview and our own analysis. In this analysis, we used data from 14 (Assignment 2) and 15 (Assignment 3) students. The other students were left out because they did not mention one of the three conclusions or because of missing data.

Student and expert interviews. We marked fragments in the transcripts related to the identification of rhetorical moves (For example: 'This is a conclusion because...'). Then, the two researchers compared and discussed the selected fragments.

The transcripts were used to determine how our subjects identified rhetorical moves. For this purpose, we surmised that rhetorical moves can possibly be identified by content-based, organizational, and lexical features. For example, conclusions can be described as answers to research questions (content-based feature), occur in the Discussion section (organizational feature), and often contain reporting verbs -e.g. suggests, found, show- and transition words/phrases -e.g. overall, so, in summary (lexical features). Grounds consist of experimental results (content-based feature), occur in the Results and Discussion section (organizational feature), and can contain reporting verbs and references to graphs or tables (lexical features).

We also determined what kinds of reading strategies students used by analysing the transcripts and observation notes. Two researchers read the transcripts and obervation notes independently and marked fragments which related to reading strategies. For further analysis, we used an adapted subdivision of Brill et al. (2004): (a) connecting prior knowledge (recognising a technical term from a lecture), (b) using illustrations (looking at a graph to understand the 
experimental procedures), (c) making predictions (interpreting a graph before reading the interpretation of the author), (d) ignoring technical terms, (e) using the internet (looking up technical terms), (f) repeated reading (rereading certain parts of the article), (g) sequential reading, and (h) selective reading.

\section{Results}

\section{Identification of conclusions by experts and students}

The experts independently identified the conclusions in Articles 1 and 3. The sentences students identified as main conclusion in Articles 1,2, and 3 are shown in Tables 1, 2, and 3 respectively. With asterisks and daggers we show which of these sentences were also mentioned by the experts.

Regarding Article 1, the experts both identified eight sentences in the text. Five of these sentences were the same with both experts (the experts identified in total 11 sentences), so there was considerable agreement between the experts. Both experts agreed that Sentence 1A (Table 1) was the most important conclusion. All the sentences identified as conclusions by our own move analysis in Table 1 were also seen as conclusions by one or both experts, except for Sentence 1J (Table 1). It has to be noted that not all experts' conclusions are included in Tables 1 and 3, because the tables only contain sentences mentioned by students as main conclusion.

Regarding Article 3, Expert A phrased as main conclusion (because he paraphrased his answer, we could not link his conclusions with one of the sentences in the tables): ' $\mathrm{O}$ the 2 doses of darbepoetin ( 0.75 and $1.5 \mu \mathrm{g} / \mathrm{kg}$, injected once a week for 8 weeks) only the highest

Comment [EVL27]: Added a comment which explains why table 1 does not include all the experts' conclusions.

Comment [EVL28]: Added a comment which explains why his conclusions are not visible in table 3. dose improves cardiac function and architecture in a rat model of myocardial infarction. The mechanism is unknown.' In addition, he phrased three minor conclusions: 
[Insert Tables 1, 2, 3, and Figure 1 about here]

Students predominantly identified sentences from the Discussion section as conclusions. In total, students identified 36, 35, and 24 sentences as conclusions in Articles 1, 2, and 3, but only the sentences mentioned as main conclusions are shown in the tables. Not all identified sentences are actual conclusions; students also identified findings and statements of result as conclusions. This was especially the case for Article 2. The average number of sentences identified as conclusions was 10.9 (Article 1), 7.1 (Article 2), and 6.2 (Article 3). So, as the course progressed, students identified on average less sentences as conclusions (Figure 1). With 16 of the 20 students we saw a reduction in the number of sentences identified as conclusion (comparing Assignment 1 with Assignment 3) - even though Article 3 has approximately 2000 more words than Article 1.

In Tables 1, 2, and 3 we underlined the reporting verbs and transition words/phrases which could signal a conclusion. It is interesting to observe that Table 2, in stark contrast to Tables 1 
and 3, contains only two sentences with a reporting verb or transition phrase.

We observed that students identified on average more conclusions than the experts did. The students identified on average 10.9 sentences in Article 1 (with very varied scores - four students identified five or less sentences, five students identified six to nine sentences and 10 students identified 10 sentences or more), while the experts identified only eight each. The same difference, although less pronounced, was seen in Article 3. Nevertheless, as the course progressed, students identified on average less sentences as (main) conclusions. It is interesting to observe that the sentences the students identified in Articles 1 and 3 almost always contained a reporting verb or transition phrase. This in contrast to the sentences identified in Article 2. It also seems that there was (compared with Articles 1 and 3) less consensus between the students about the main conclusion of Article 2: there was not a single sentence which was identified as main conclusion by a majority of the students. However, there was considerable agreement between students and experts regarding the main conclusion of Articles 1 and 3. With the exception of Article 3, students identified a wide range of sentences which were not seen as conclusions by the experts or by our own move analysis. Instead, the students identified a great number of findings and statements of results as conclusions. Furthermore, it should be noted that not all conclusions found by our move analysis were recognised as such by our experts.

Regarding Article 3, it is interesting to observe that 10 of the 20 students combined two conclusions: the one which described the effects of the treatment (attenuation of cardiac modelling and an improvement of cardiac function) and the one which described a possible mechanism (EPC mobilisation and increasing capillary density) for these effects. In contrast, the experts did not cluster these conclusions: they made a clear distinction between these two. 


\section{Features used by experts and students for identifying conclusions}

We asked the experts how they identified conclusions. As Expert A stated in the interview, a conclusion is the answer to the research question. 'And one has data to justify it. But data are only data. They only have meaning in a context. And that is the conclusion. (...) in the research question you have the context taken into account and you have tried to manipulate it so that you can use the data to reach a certain conclusion.' According to Expert B, the conclusion is the summarised answer to the questions of the authors, justified with data.

Expert A stated that a conclusion should really stay close to the data. Additionally, there are conclusions which are placing the research into perspective ('like... what does this mean for humankind, for the climate problem, for the expansion of the universe'). Expert B made another distinction: there is a main conclusion (which is rather broad) and there are minor conclusions (or sub-conclusions) which are pointing to the main conclusion.

Expert A added to this remark that there are two types of sub-conclusions. There are subconclusions which 'specify the broad, big thing' and there are sub-conclusions which consists of information that can be useful to other researchers. For example, 'method A is superior to method B, C and D because of...'

When they determined the importance of conclusions, the experts used three criteria: (1) does it answer the research question, (2) how 'big' is the conclusion, and (3) how much evidence is given? Furthermore, the experts used domain knowledge while they determined the importance of conclusions. Take, for example, the following conclusion which was identified by Expert A: 'It is interesting to observe that these values were already modified within 24 hours of the infarction and the ECHO was sensitive enough to detect these alterations precociously.' 
According to him this was a reasonably important conclusion, because the researchers 'themselves, I think, had never expected that the first time point was suitable.'

When the experts examined the students' answers (Table 1), they noted that some of the students' sentences were not conclusions but results. An example is Sentence 1B (Table 1). As Expert A said: 'This is in my view not a conclusion, because it is a description of the data. (...) This is a nice sentence which describes relations between data, but it does not give an interpretation.' Expert B added: 'It describes something and it is maybe important data (...) on the basis of this you (...) have to make a conclusion.'

The students also identified Sentence $1 \mathrm{~J}$ (Table 1) as conclusion. According to Expert A, this was not a conclusion because the sentence contained no new information. 'This is intrinsic to the model: you always see this. (...) This is known for years.'

We also asked the four interviewed students how they identified conclusions. According to Bill and Jessica, a conclusion is the answer to the research question. Bill remarked that the research question and the conclusion are sometimes formulated in the same way: 'The question was: can an ECG do this. And if you read: this ECG can do or can't do this... then... so it is formulated a little bit the same as the question. Then... I think: hey, that's a conclusion.' Bill, like Mary, also used textual markers (like 'we conclude...') to identify conclusions. Nevertheless, Mary found it difficult to distinguish conclusions from other statements. Interestingly, Jessica also said that a conclusion could be a sort of summary. She stated: 'Here they really state the conclusion. At this point they summarise it shortly.' Leah also thought that conclusions could be a summary: 'They summarise a little bit the previous text and they tell what you can do with it (...) and it is an important advance [in the research field] (...) so it seems 
a conclusion to me.' Later on, Leah stated that a conclusion could also be an explanation: '....and then they explain why, so I think this is also a conclusion.'

How did the students decide how important each conclusion was? Jessica reasoned that the most important conclusion is the one that answers the most important research question. And, according to Jessica, the most important research question is the one that is mentioned first by the authors. As Jessica put it, when asked why a certain conclusion was the most important one: 'Because... that one... that one is the answer to the first research question (...) that is the first thing they want to know.' Leah used another method. According to her, the most important conclusions were the ones that summarise the research and tell what you can do with it. The conclusions which were 'directly deduced from the results' were less important.

We observed a number of differences between experts and students on the identification of conclusions. The experts used rather specific content knowledge when they identified conclusions and rated their importance. For example, they saw a certain sentence not as conclusion, because the information was not new. Students used also lexical features (like reporting verbs) and organizational features (like the place of the sentence in the paragraph) even though they understood the articles rather well (according to themselves). Furthermore, the students formulated two different definitions of a conclusion: it answers the research question and it summarises the results. The experts defined the conclusion only as an answer to the research question(s).

\section{Identification of grounds by experts and students}

Experts' written answers regarding the identification of grounds (see the section Genre 

For example, the conclusions for which expert A gave grounds, were phrased by himself. This made student-expert comparisons difficult. So, for the analysis of the students' answers we used experts' comments in the interview and our own content knowledge. We observed that the experts preferred to use data sources as grounds (e.g. 'CD31 data'). Both experts did not mention citations as grounds.

We analysed written assignments 2 and 3 to elucidate which kinds of grounds students identified. We grouped 17 students' grounds and determined how many times an inscription, statement of result, finding, citation, and another conclusion was mentioned (Table 4). In total, the 17 students gave grounds for 109 (Assignment 2) and 74 (Assignment 3) text fragments. These fragments were not necessarily unique and often contained multiple sentences; students tended to give grounds for aggregations of conclusions. Students most often mentioned inscriptions as grounds. Citations were also frequently mentioned. Conclusions were least frequently mentioned as grounds (Table 4).

We also analysed the completeness and correctness of grounds for Assignments 2 (Table 5) and 3 (Table 6). To this end, we classified the grounds on the basis of the data sources used in the articles (and not according to Dudley-Evans, 1994). This analysis was done for a selection of three conclusions in each article. It is noteworthy to observe that the students did not always mention the most important grounds for a conclusion. For example, in Assignment 3, only two of the eight students mentioned the (rather important) heart function data as ground for Sentence 3A. However, students' grounds were most of the times correct; i.e. they referred to the right data sources. Of all the 32 grounds mentioned by students in Table 5, only three were incorrect. The same goes for Table 6: of all the 36 grounds, only eight were incorrect. 


\section{Features used by experts and students for identifying grounds}

What features do experts use to identify grounds in an article? Experts saw the grounds (or evidence, as they call it) as among the most important aspects of an article. As Expert A said: 'The body of evidence in an article is very important and you continually look back at it. In fact, I'm interested in the conclusions of the authors, but more to direct my own thinking process.' According to Expert A, it is necessary to form your own conclusions, because the conclusions of authors are not always uncontested. However, the most important evidence can be found in the Discussion section. As Expert A said about writing the Discussion: 'If you just say: well, this does it... look, go to the data... then it will be a little bit a puzzle. So usually, I try to mention the two or three most important grounds before [the conclusion].'

When asked what they expected from students regarding the identification of grounds, they stated that they want students to mention at least one reference to the results per conclusion. They rather see that students refer to original data than to cited research. Citations are, according to the experts, weak evidence. Expert B: 'You have to show it yourself.'

We also interviewed our four students about the identification of grounds. When Leah tried to find the grounds of the conclusions of Article 2, she admitted that she found it rather difficult: 'Sometimes I didn't have a clue where [the authors] got it from.' She often looked for textual clues (rather than via inferring) when deciding which ground belonged to a certain conclusion. Take, for example, Sentence $2 \mathrm{H}$ (Table 2). According to Leah, this sentence was justified by a 
table in which RR-intervals are given. When asked why, she remarked: 'Because it's about the RR-interval.' Leah distinguished three types of grounds: results, citations, and other conclusions. Results are the most important grounds, according to Leah: 'Because they just measured it, so you know for sure that it is true.' The second most important grounds are other conclusions. The least important grounds are citations, because 'literature can be obsolete or superseded'.

Jessica was better able to explain the relationship between her grounds and conclusions of Article 3. She looked more at the content of the conclusion, before deciding which grounds were related to it. She made a distinction between the main conclusion (which was justified by 'all the results') and other conclusions (which were justified by authors' results or citations).

Mary had a similar approach: she looked at each figure and table and then decided which conclusion related to it. For example: 'Let's see. Figure 5 (...) I think the black bar indicates that it's higher... that there are more EPC's mobilised and that's what the conclusion also says.'

In summary, it seems that students like to stay as close to the original data as possible when they have to give grounds for conclusions. A table or graph is more likely seen as ground than an interpretation of said inscription (e.g. statement of result, finding or conclusion). On the whole, the grounds given by students were correct. The grounds they mentioned mostly matched with their conclusions. However, students sometimes failed to mention important grounds for a particular conclusion. Students seemed to prefer the use of inscriptions as grounds, but also referred to statements of results and findings. This in contrast to experts, who did prefer to mention only a general description of the data source (e.g. 'CD31 data'). Another difference between experts and students was the use of citations as grounds. Experts did not attach much importance to citations and did not mention these as grounds, while students occasionally 


\section{Reading strategies used by students}

To give an impression how students deal with the task of reading a research article, we now present the reading strategies of four students: Bill, Jessica, Leah, and Mary.

Bill. When reading the article for the first time, Bill used a sequential reading style. He seldom jumped back and forth. However, he adopted a more non-sequential reading style when making the assignment. Bill skimmed his articles, so he read rather quick. He spent 1 hour and 10 minutes on Assignment 1 and 1 hour and 30 minutes on Assignment 3 (including reading the article). Bill skipped some parts of the article (for example the paragraph about the statistical analysis, because 'for this assignment it is not important'). Bill also found the Discussion much more important than the Results section. 'I understood the conclusions, and that is (...) what is really important for an article. (...) How they came to it... that is more... more a proof like: it is really the case.'

Bill did not pay much attention to inscriptions. Instead he looked for verbal descriptions of tables and figures. As Bill said: 'Here they say in words what was presented in the table. That's easy.' Bill skipped sentences in which previous research was referenced. As he said: 'If you read: those and those have studied this, that's not interesting.'

Bill tended to ignore unknown technical terms. Bill thought it would be much effort for little gain to look them up: 'Now they describe their methods. That's not very interesting. 
Because... things like the Simpson's method... Well, I have to look up who Simpson is. And this is probably more work than it is worth.' However, he looked up one technical term on the internet during Assignment 1, and two technical terms during Assignment 3.

Jessica. Jessica read her texts mainly sequentially during the first reading and seldom jumped back and forth. Later on, while making the assignment, she adopted a more nonsequential reading style. She spent $1 \mathrm{hr} 45 \mathrm{~min}$ on Assignment 1 and $2 \mathrm{hr} 10 \mathrm{~min}$ on Assignment 3.

While reading, Jessica tried to develop her own explanations and predictions. 'Well, so apparently it is different when they look at the dead rat... when they look what the... yes... what the condition is of the heart. But I think what happens next is that it will get worse or something like that. That you first have an infarct and that after a certain amount of time... that they see that the situation will get even more worse.' While reading the results, Jessica tried to interpret the findings of the authors. For example: 'There is a reduction in the amplitude (...) so the situation gets worse.' Or: 'Well, it looks like their hypothesis is correct.' Jessica admitted that she reads the Results section quite intensively. 'Yes... actually... I spend maybe too much time on it. But I find it interesting to read.'

Jessica did not pay much attention to the article's inscriptions. 'Everything is in the text. I only look at graphs and tables if I'm confused about something.' After reading the Discussion of Article 1, Jessica said that reading the results had made understanding the Discussion easier. 'It's really valuable to read the results. It makes things clearer. Because... yes, otherwise... I don't think I could have understand quite as good what they were saying.'

Jessica seemed to be the only one of the four students who actively compared results from referenced research with the authors' results. Jessica did not frequently look up words on the 
internet: 'First I try to read further as much as possible to see if I can make out [the meaning of a term]. If I can't I will look them up on the computer.' She looked up 2 technical terms during Assignment 1. During Assignment 3 she did not look up technical terms.

Leah. Just like Jessica and Bill, Leah read sequentially during her first reading. When making the assignment, she began to jump back and forth. Leah skimmed the article and spent 2 hr 5 min on Assignment 2. She read the whole article (minus the Abstract), but did not 'take up' everything, especially the method and the Results section. Instead, she tried to distil the big picture. Leah did not pay much attention to the inscriptions. Leah ignored sentences in which previous research was mentioned, because 'you don't need it.' She remarked: 'It is only a small report of old studies.' She also ignored technical terms and did not look them up on the internet.

Mary. Mary was the only student who read non-sequentially right from the start. She began with reading the Abstract ('to look what kind of research they actually do and what they want to achieve with it') and then read the Discussion section. She reasoned that reading the Discussion section was the best way to start when you have to identify the conclusions. Then she read the Method section. In hindsight, she did not think that her reading strategy was sensible, because in the beginning she had great difficulty with understanding the content of the article. 'If I had read it calmly from the beginning... then I would have understand it better at once.'

Mary tried to interpret the data presented in the article. Although she did not read the text of the Results section, she did study the figures and tables quite thoroughly. 'First I try to interpret the figures a little bit (...) and if this fails you read the text, of course. I always read the caption (...) much will be clear on the basis of graphs.' She did this because she found the text in the Results section which described the data 'very abstract'. She spent $1 \mathrm{hr} 45$ min on Assignment 3. She looked up five technical terms on the internet. 
In general, our students read selectively and sequentially. Furthermore, Bill and Leah used rather pragmatic reading strategies. In contrast, the reading strategies of Jessica and Mary were more active; e.g. they made predictions. All students said they understood the articles. However, we observed some comprehension difficulties, especially regarding the technical terms in the Method section. The students dealt in different ways with these difficulties. Bill and Leah tended to ignore unknown technical terms, while Jessica and Mary tried to find out their meaning on the internet. Overall, we encountered similar strategies as Brill et al. (2004).

\section{Discussion}

Regarding the identification of conclusions, our results suggest that students, in contrast to experts, rely heavily on organizational and lexical features while reading a research paper. The students were able to find the most important conclusion (according to the experts), although the other sentences they identified as conclusions were quite different from the experts. Students referred to sentences that were according to the experts definitely not conclusions. Experts were using more content-based features for the identification of conclusions. This is probably the reason why some of the sentences we identified as conclusions in our own move analysis (based on Dudley-Evans, 1994) were not identified as such by the experts. For example, Sentence 1J (Table 1) was not seen as conclusion by the experts because it contained no new information.

These findings correspond with Dee-Lucas and Larkin (1988), who discovered that novice and expert readers used different rules for judging the importance of certain text elements. Novice readers tend to judge the importance of sentences by their form, while expert readers judge the importance of sentences by their content. For example, 'novices consider the same 
substantive information to be more important when presented as a definition (rather than a fact) and as an equation (rather than a verbal phrase)' (Dee-Lucas and Larkin, 1988, p. 306). This socalled 'form effect' was not seen in the group of experts.

When students identify grounds, we see the reverse: the grounds are correct (i.e. referred to matching data or data interpretations), but students do not always mention the most important ones. Sandoval and Millwood (2005) described similar problems when high school students gave written explanations for two problems of natural selection - using existing data sets that students could explore with a special computer software. They saw that students had difficulty with citing sufficient evidence for claims and linking specific inscriptions (figures or tables) to particular claims. Kelly, Regev, and Prothero (2008) described some criteria for determining the quality of (written) scientific argumentation. One of these criteria is the coordination of evidence across epistemic levels in articles: the explicitation of 'how particular inscriptions or claims provide evidence for higher order, more generalized claims' (p. 133). Our results imply that understanding this coordination of evidence is quite challenging for students when reading a research article.

We found that the interviewed undergraduate students read their articles selectively. They skipped or skimmed for example the Method section, because they thought it was not relevant for the assignment. Our students (with one exception) read their articles sequentially. Experts, who have disparate purpose laden schema, read differently: they read selectively, just like students, but unlike students they read non-sequentally (Bazerman, 1988).

The choice of articles could have influenced our results. For instance, it is possible that the textual organization could have affected students' answers. The main conclusion of Articles 1 and 2, for example, was placed at the beginning of the Discussion, while the main conclusion of 
Article 3 was placed at the end. However, in both cases students seem to be able to find the main conclusion. Other textual features could also have influence. Article 2, a correlation study, contains a vague research goal (' $\ldots$ to gain insight into the relations of these variables and HR variability to mortality') compared to Articles 1 and 3.|This could explain why there was less consensus in students' anwers to Assignment 2.

The interviewed students seemed to have no major problems with understanding the concepts used in the articles (apart from some technical terms, see also Brill et al., 2004). This is probably due to the lectures students attended before reading the articles, in which relevant concepts were presented. This ensured that students had sufficient prior knowledge. It is generally accepted that prior knowledge plays a substantial role in text comprehension. Ozuru (2009) suggests that readers' level of prior knowledge is even more important than their general reading skills for comprehending expository science texts.

Our students were non-native speakers of English. We surmise that this factor did not have a significant impact on text comprehension. On the whole, [nationality] students are well-versed in English language. All textbooks students use are in English, so they have ample experience in reading English science texts. Furthermore, research suggests that students' language skills play a much less important role than conceptual knowledge with respect to the comprehension of scientific texts (Chen \& Donin, 1997).

It would be worthwhile if we could advance students' skills to a higher level of competency in such a way that they gradually use more expert-like strategies while reading and understanding a research article. To achieve this aim, we want to combine ideas from genre analysis and cognitive apprenticeship into a teaching strategy. By reading research articles students gain generic practice: '...the ability to respond to recurrent and novel rhetorical 
situations by constructing, interpreting, using and often exploiting generic conventions embedded in specific disciplinary cultures and practices to achieve professional ends' (Bhatia, 2004, p. 144). In this way, students are slowly becoming part of a community of practice. Integration into a community of practice is described by Lave and Wenger (1991) as 'legitimate peripheral participation'.|The scientific community in which our students were absorbed by legitimate peripheral participation can be described as a summation of many different activity systems. An activity system can be defined as 'any ongoing, object-directed, historicallyconditioned, dialectically-structured, tool-mediated human interaction (....) These activity systems are mutually (re)constructed by participants using certain tools and not others (including discursive tools such as speech sounds and inscriptions)' (Russell, 1997, p. 510).

We can distinguish some notable differences between the activity systems of students and experts regarding reading research articles. 1) Due to their experience in reading and writing research articles, experts have a better grasp of the rhetorical moves used in research articles. Experts know how conclusions are interwoven in the Discussion section of an article. They know which semantic structures authors use to connect grounds with conclusions. They have, in other words, 'rhetorical consciousness'. Students do not possess this kind of knowledge. 2) Experts have a better understanding of the conceptual/epistemological nature of argumentative elements like the conclusion and grounds. Experts know better which conclusions and which grounds are valid or not. 3) Experts have more prior knowledge than students. Experts usually are familiar with the technical terms mentioned in research articles and understand immediately why and how certain experiments have been done and how to interpret the presented data. Furthermore, they have access to tools (like handbooks) which can help them understanding the article. This makes it easier for experts to follow the lines of reasoning in an article. 4) Experts read with a

Comment [EVL50]: Removed: "An activity system consists of a subject, object, tools, rules, community, and division of labor (Engeström, 1987).'

\section{Comment [EVL51]: Removed:} 'Students and experts function in different activity systems'.

\section{Comment [EVL52]: 'between} students and experts' replaced by 'between the activity systems of students and experts regarding reading research articles'

\section{Comment [EVL49]:}

Removed: 'Ultimately, this process
will lead to full participation in a community of practice.' 
different goal than students, because they function in a different community. Students' reading is assignment driven, while experts read because they want to incorporate the information into their research.

In conclusion, our study demonstrates that our students are to a certain degree able to read and understand research articles. Our results show that students and experts defined conclusions and grounds in different ways. Students and experts agreed on the most important conclusion of the articles. However, students identified a wide range of sentences which were not seen as conclusions by the experts. The grounds students mentioned mostly matched with their conclusions. However, in some cases students failed to mention important grounds for a particular conclusion.

In our future teaching strategy, we want to focus on the abovementioned first and second student-expert differences. The other differences are more difficult to bridge. It is impossible to bring the knowledge of students on a par with experts in the short period of a course and the goals of students and experts are often quite different while reading a research article. So, in our future teaching strategy we will direct our attention to the textual structure of scientific text and the conceptual/epistemological nature of rhetorical elements. Students should be given clear, transferable criteria for identifying these elements. Future research will elucidate if this teaching strategy will improve students' reading skills.

\section{References}

Bazerman, C. (1988). Shaping written knowledge: The genre and activity of the experimental article in science. Madison: University of Wisconsin Press.

Comment [EVL54]: Removed: 'undergraduate students are not always doing research, so reading articles will often be assignment driven - although in recent years some educators have emphasised the importance of research-based teaching in higher education (Griffiths, 2004).'

Comment [EVL55]: Changed the order of sentences.

Comment [EVL56]: Removed: 'They are, for example, sometimes confused about what a conclusion entails. These criteria must be conceptual/epistemological and structural, so that students are encouraged to focus on content and form.'

Comment [EVL57]: Added a new closing sentence.
Comment [EVL53]: Added the 
Berkenkotter, C., \& Huckin, T. (1994). Genre knowledge in disciplinary communication: Cognition/Culture/Power. Hillsdale, NJ: Lawrence Erlbaum Associates.

Bhatia, V. K. (2004). Worlds of written discourse: A genre-based view. London: Continuum.

Brett, P. (1994). A genre analysis of the results section of sociology articles. English for Specific Purposes, 13, 47-59.

Brill, G., Falk, H., \& Yarden, A. (2004). The learning processes of two high-school biology students when reading primary literature. International Journal of Science Education, 26, 497-512.

Charney, D. (1993). A study in rhetorical reading: How evolutionists read 'The Spandrels of San Marco'. In J. Selzer (Ed.), Understanding scientific prose (pp. 203-231). Madison: University of Wisconsin Press.

Chen, Q., \& Donin, J. (1997). Discourse processing of first and second language biology texts: Effects of language proficiency and domain-specific knowledge. Modern Language Journal, $81,209-227$.

Connor, U., Upton, T. A., \& Kanoksilapatham, B. (2007). Introduction to move analysis. In D. Biber, U. Connor, \& T. A. Upton (Eds.), Discourse on the move: Using corpus analysis to describe discourse structure (pp. 23-41). Amsterdam: John Benjamins.

Cook, L. K., \& Mayer, R. E. (1988). Teaching readers about the structure of scientific text. Journal of Educational Psychology, 80, 448-56.

Day, R. A. (1998). How to write and publish a scientific paper. Cambridge: Cambridge University Press.

Dee-Lucas, D., \& Larkin, J. (1988). Novice rules for assessing importance in scientific texts. Journal of Memory and Language, 27, 288-308. 
Dudley-Evans, T. (1994). Genre analysis: An approach to text analysis for ESP. In M. Coulthard (Ed.), Advances in written text analysis (pp. 219-228). London: Routledge.

Erduran, S., \& Jiménez-Aleixandre, M. P. (2008). Argumentation in science education: An overview. In S. Erduran, \& M. P. Jiménez-Aleixandre (Eds.), Argumentation in science education: Perspectives from classroom-based research (pp. 3-27). Dordrecht, The Netherlands: Springer.

Fang, Z. (2005). Scientific literacy: A systemic functional linguistics perspective. Science Education, 89, 335-347.

Flesch, R. (1948). A new readability yardstick. Journal of Applied Psychology, 32, 221-233.

Gillen, C. M. (2006). Criticism and interpretation: Teaching the persuasive aspects of research articles. CBE Life Sciences Education, 5, 34-38.

Goldin, G. A. (2000). A scientific perspective on structured, task-based interviews in mathematics education research. In A. E. Kelly \& R. A. Lesh (Eds.), Handbook of research design in mathematics and science education (pp. 517-545). Mahwah, NJ: Lawrence Erlbaum.

Gross, A. G., Harmon, J. E., \& Reidy, M. (2002). Communicating science: The scientific article from the 17th century to the present. Oxford: Oxford University Press.

Hill, S. S., Soppelsa, B. F., \& West, G. K. (1982). Teaching ESL students to read and write experimental-research papers. TESOL Quarterly, 16, 333-347.

Holliday, W. G., Yore, L. D., \& Alvermann, D. E. (1994). The reading-science learning-writing connection: Breakthroughs, barriers, and promises. Journal of Research in Science Teaching, $31,877-893$. 
Jacques-Fricke, B. T., Hubert, A., \& Miller, S. (2009). A versatile module to improve understanding of scientific literature through peer instruction. Journal of College Science Teaching, 39(2), 24-32.

Janick-Buckner, D. (1997). Getting undergraduates to critically read and discuss primary literature. Journal of College Science Teaching, 27(1), 29-32.

Kanoksilapatham, B. (2005). Rhetorical structure of biochemistry research articles. English for Specific Purposes, 24, 269-292.

Kleiger, R. E., Miller, J. P., Bigger, J. T.,Jr, \& Moss, A. J. (1987). Decreased heart rate variability and its association with increased mortality after acute myocardial infarction. The American Journal of Cardiology, 59, 256-262.

Kuldell, N. (2003). Read like a scientist to write like a scientist: Using authentic literature in the classroom. Journal of College Science Teaching, 33(2), 32-35.

Lave, J., \& Wenger, E. (1991). Situated learning: Legitimate peripheral participation. Cambridge: Cambridge University Press.

Levine, E. (2001). Reading your way to scientific literacy. Journal of College Science Teaching, $31(2), 122-125$.

Miranda, A., Costa-e-Sousa, R. H., Werneck-de-Castro, J. P., Mattos, E. C., Olivares, E. L., Ribeiro, V. P., Silva, M. G., Goldenberg, R. C., \& Campos-de-Carvalho, A. C. (2007). Time course of echocardiographic and electrocardiographic parameters in myocardial infarct in rats. Anais da Academia Brasileira de Ciências, 79, 639-48.

Muench, S. B. (2000). Choosing primary literature in biology to achieve specific educational goals. Journal of College Science Teaching, 29(4), 255-260. 
Mulnix, A. B. (2003). Investigations of protein structure and function using the scientific literature: An assignment for an undergraduate cell physiology course. Cell Biology Education, 2, 248-255.

Ozuru, Y., Dempsey, K., \& McNamara, D. S. (2009). Prior knowledge, reading skill, and text cohesion in the comprehension of science texts. Learning and Instruction, 19, 228-242.

Peacock, M. (2002). Communicative moves in the discussion section of research articles. System, $30,479-497$.

Peck, W. H. (2004). Teaching metastability in petrology using a guided reading from the primary literature. Journal of Geoscience Education, 52, 284-288.

Prunier, F., Pfister, O., Hadri, L., Liang, L., Del Monte, F., Liao, R., \& Hajjar, R. J. (2007). Delayed erythropoietin therapy reduces post-MI cardiac remodeling only at a dose that mobilizes endothelial progenitor cells. The American Journal of Physiology - Heart and Circulatory Physiology, 292, 522-529.

Purcell-Gates, V., Duke, N. K., \& Martineau, J. A. (2007). Learning to read and write genrespecific text: Roles of authentic experience and explicit teaching. Reading Research Quarterly, 42, 8-45.

Russell, D. R. (1998). Rethinking genre in school and society: An activity theory analysis. Written Communication, 14, 504-554.

Sandoval, W. A., \& Millwood, K. A. (2005). The quality of students' use of evidence in written scientific explanations. Cognition \& Instruction, 23, 23-55.

Swales, J. M. (1981). Aspects of article introductions. Birmingham, United Kingdom: The University of Aston, Language Studies Unit. 
Swales, J. M. (1990). Genre analysis: English in academic and research settings. Cambridge: Cambridge University Press.

Tenopir, C., King, D. W., Edwards, S., \& Wu, L. (2009). Electronic journals and changes in scholarly article seeking and reading patterns. Aslib Proceedings, 61, 5-32.

Thomas, S., \& Hawes, T. P. (1994). Reporting verbs in medical journal articles. English for Specific Purposes, 13, 129-148.

Thompson, D. K. (1993). Arguing for experimental "facts" in science: A study of research article results sections in biochemistry. Written Communication, 10, 106-128.

Toulmin, S. E., Rieke, R. D., \& Janik, A. (1979). An introduction to reasoning. New York: Macmillan.

van Gelder, T. (2005). Teaching critical thinking: Some lessons from cognitive science. College Teaching, 53, 41-46.

van Someren, M. W., Barnard, Y. F., \& Sandberg, J. A. C. (1994). The think aloud method: A practical guide to modelling cognitive processes. London: Academic Press.

Williams, I. A. (1999). Results sections of medical research articles: Analysis of rhetorical categories for pedagogical purposes. English for Specific Purposes, 18, 347-66.

Yarden A. (2009). Reading scientific texts: Adapting primary literature for promoting scientific literacy. Research in Science Education, 39, 307-311.

\section{Acknowledgements}

Our sincere gratitude to [name], [name], and the students and tutors of the course 'Biomedical Research'. 
Table 1

Sentences identified as main conclusion by students $(\mathrm{n}=19)$ in Article 1.

\begin{tabular}{|c|c|c|c|c|c|}
\hline I & II & III & IV & $\mathrm{V}$ & VI \\
\hline $1 \mathrm{~A}$ & $\mathrm{D}$ & $\begin{array}{l}\text { In summary our data show that ECG and ECHO detect non- } \\
\text { invasively MI in rats and that these methods can be used to estimate } \\
\text { infarct size. }\end{array}$ & 17 & 16 & Conclusion \\
\hline 1B & $\mathrm{D}$ & $\begin{array}{l}\text { The most significant correlations were found between } \\
\text { echocardiographic parameters and infarct size as measured by } \\
\text { histopathology; among these, LV diastolic and systolic volumes } 7 \\
\text { days after MI, and M-mode SF\% and EF\% at } 7 \text { and } 28 \text { days post-MI. }\end{array}$ & 10 & 8 & Finding \\
\hline $1 \mathrm{C}$ & $\mathrm{D}$ & $\begin{array}{l}\text { Our data further suggest that the } 7 \text { day interval is actually the most } \\
\text { accurate for estimation of infarct size by echocardiography. }{ }^{* \dagger}{ }^{*}\end{array}$ & 8 & 5 & Conclusion \\
\hline $1 \mathrm{D}$ & $\mathrm{D}$ & $\begin{array}{l}\text { These data suggest that the best time point to estimate infarct size by } \\
\text { M-mode } \mathrm{CHO} \text { is at } 7 \text { days post-surgery. }{ }^{*}+\end{array}$ & 17 & 3 & Conclusion \\
\hline $1 \mathrm{E}$ & A & $\begin{array}{l}\text { In summary we show that conventional ECG and ECHO methods } \\
\text { can be used to estimate infarct size in rats. }\end{array}$ & 3 & 3 & Conclusion \\
\hline $1 \mathrm{~F}$ & $\mathrm{D}$ & $\begin{array}{l}\text { Overall, the conventional ECG is an excellent marker for MI but a } \\
\text { poor predictor of infarct size. }{ }^{* \dagger}\end{array}$ & 15 & 2 & Conclusion \\
\hline $1 \mathrm{G}$ & $\mathrm{D}$ & $\begin{array}{l}\text { By ECHO we found a correlation between infarct size and LV } \\
\text { dilatation only at } 7 \text { days post MI. }\end{array}$ & 9 & 2 & Finding \\
\hline $1 \mathrm{H}$ & $\mathrm{D}$ & $\begin{array}{l}\text { A negative correlation between infarct size and ejection fraction and } \\
\text { shortening fraction by M-mode was found at } 7 \text { and } 28 \text { days post MI } \\
\text { (Figs. 2-C and 2-D). }\end{array}$ & 9 & 2 & Statement of result \\
\hline 1I & $\mathrm{D}$ & $\begin{array}{l}\text { Thus, in the examinations at } 28 \text { days post-infarct, a positive } \\
\text { correlation between E/A ratio and infarct size was found, suggesting } \\
\text { that animals with a larger infarct have greater diastolic dysfunction. }\end{array}$ & 13 & 1 & Finding/Conclusion \\
\hline $1 \mathrm{~J}$ & $\mathrm{D}$ & $\begin{array}{l}\text { These findings imply that besides systolic dysfunction, the infarcted } \\
\text { group also has important diastolic dysfunction. }\end{array}$ & 13 & 1 & Conclusion \\
\hline $1 \mathrm{~K}$ & $\mathrm{R}$ & $\begin{array}{l}\text { This implies that M-mode echocardiography can be used as an } \\
\text { estimate of infarct size in this time interval. }\end{array}$ & 6 & 1 & Conclusion \\
\hline $1 \mathrm{~L}$ & $\mathrm{D}$ & $\begin{array}{l}\text { The echocardiogram is a useful tool in the evaluation of cardiac } \\
\text { function and alterations in the morphology of the heart in a } \\
\text { noninvasive form. }\end{array}$ & 6 & 1 & Information move \\
\hline $1 \mathrm{M}$ & $\mathrm{R}$ & $\begin{array}{l}\text { Importantly, on day } 7 \text { post-infarction, there was a negative } \\
\text { correlation between infarct size, ejection and shortening fraction } \\
\text { determined by M-mode as shown in Figures 2-C, 2-D. }\end{array}$ & 3 & 1 & Statement of result \\
\hline $1 \mathrm{~N}$ & $\mathrm{R}$ & $\begin{array}{l}\text { Negative correlation was also found between infarct size, ejection } \\
\text { and shortening fraction on day } 28 \text { post-surgery } \mathrm{R}=-0.63, \mathrm{p}<0.05 \text {, } \\
\mathrm{N}=11 ; \mathrm{R}=-0.65, \mathrm{p}<0.05, \mathrm{~N}=11 \text {; respectively) and }[\mathrm{t}] \text { here is } \\
\text { correlation between } \mathrm{E} / \mathrm{A} \text { ratio and infarct size at } 28 \text { days post } \\
\text { infarction }(\mathrm{R}=0.71, \mathrm{~N}=10, \mathrm{p}=0.02) \text {. }\end{array}$ & 3 & 1 & Statement of result \\
\hline 10 & $\mathrm{R}$ & $\begin{array}{l}\text { Our data suggest that the 7-day interval is actually the most accurate } \\
\text { for estimation of infarct size by ECHO. }\end{array}$ & 2 & 1 & Conclusion \\
\hline
\end{tabular}

Note. Column II: Location of the sentence (A=Abstract, $\mathrm{R}=$ Results, $\mathrm{D}=$ Discussion).

Column III: Sentence identified as main conclusion. Column IV: Number of students who mentioned this sentence as conclusion. Column V: Number of students who mentioned this sentence as main conclusion. Column VI: Rhetorical move of the sentence according to authors, following Dudley-Evans (1994). Reporting verbs and transition words/phrases are underlined.

*Sentences identified as conclusion by Expert A. Sentences identified as conclusion by Expert B. 
Table 2

Sentences identified as main conclusion by students $(n=18)$ in Article 2.

\begin{tabular}{|c|c|c|c|c|c|}
\hline I & II & III & IV & $\mathrm{V}$ & VI \\
\hline $2 \mathrm{~A}$ & $\mathrm{R}$ & $\begin{array}{l}\text { Decreased HR variability increases the risk of death irrespective of average } \\
\text { HR (Fig. 2), variables reflecting left ventricular function (Fig. 3), those } \\
\text { measuring ventricular ectopic activity (Fig. } 4 \text { and 5), clinical or } \\
\text { demographic variables (Table V) or drug treatment (Table VI). }\end{array}$ & 12 & 7 & Statement of result \\
\hline $2 \mathrm{~B}$ & $\mathrm{D}$ & $\begin{array}{l}\text { The present study suggests that patients with decreased HR variability have } \\
\text { decreased vagal tone or increased sympathetic tone and may have higher } \\
\text { risk of ventricular fibrillation. }\end{array}$ & 15 & 5 & Conclusion \\
\hline $2 \mathrm{C}$ & $\mathrm{D}$ & $\begin{array}{l}\text { Furthermore, HR variability has a significant and strong association with } \\
\text { mortality during follow-up even after adjusting statistically for ventricular } \\
\text { arrhythmias detected in the same Holter recording. }\end{array}$ & 13 & 5 & Finding \\
\hline $2 \mathrm{D}$ & $\mathrm{D}$ & $\begin{array}{l}\text { Thus, the strong univariate association with mortality (the strongest of any } \\
\text { Holter variable) along with the ease and low cost of measuring HR } \\
\text { variability make it an important advance in postinfarction risk } \\
\text { stratification. }\end{array}$ & 12 & 4 & Conclusion \\
\hline $2 \mathrm{E}$ & D & $\begin{array}{l}\text { Using HR variability together with information about ventricular arrhythias } \\
\text { will improve substantially the prediction of outcome. }\end{array}$ & 9 & 3 & Conclusion \\
\hline $2 \mathrm{~F}$ & $\mathrm{D}$ & $\begin{array}{l}\text { These speculations have therapeutic implications: agents that blunt } \\
\text { sympathetic influence or agents that promote vagal influence may have } \\
\text { therapeutic value after infarction, particularly in patients with low HR } \\
\text { variability. }\end{array}$ & 4 & 2 & Conclusion \\
\hline $2 \mathrm{G}$ & A & $\begin{array}{l}\text { HR variability remained a significant predictor of mortality after adjusting } \\
\text { for clinical, demographic, other Holter features and ejection fraction. }\end{array}$ & 2 & 2 & Finding \\
\hline $2 \mathrm{H}$ & $\mathrm{D}$ & $\begin{array}{l}\text { In the present study, } \mathrm{HR} \text { variability computed from all of the RR intervals } \\
\text { in a } 24 \text {-hour continuous electrocardiographic recording made } 11 \pm 3 \text { days } \\
\text { after infarction was significantly and strongly associated with subsequent } \\
\text { mortality. }\end{array}$ & 9 & 1 & Finding/Conclusion \\
\hline $2 \mathrm{I}$ & $\mathrm{D}$ & $\begin{array}{l}\text { Beta-blocking drugs reduce the risk of mortality after myocardial } \\
\text { infarction, in part because of their antiarrhythmic and antifibrillatory } \\
\text { actions. }{ }^{33,34}\end{array}$ & 2 & 1 & Citation \\
\hline $2 \mathrm{~J}$ & A & $\begin{array}{l}\text { HR variability is a predictor of long-term survival after acute myocardial } \\
\text { infarction. }\end{array}$ & 1 & 1 & Conclusion \\
\hline $2 \mathrm{~K}$ & A & $\begin{array}{l}\text { Of all Holter variables measured, HR variability had the strongest } \\
\text { univariate correlation with mortality. }\end{array}$ & 1 & 1 & Finding \\
\hline $2 \mathrm{~L}$ & $\mathrm{R}$ & $\begin{array}{l}\text { The association of HR variability with survival is statistically significant } \\
\text { when evaluated with the proportional hazards model, using HR variability } \\
\text { as measured }\end{array}$ & 1 & 1 & Finding \\
\hline $2 \mathrm{M}$ & $\mathrm{D}$ & $\begin{array}{l}\text { HRV computed from all of the RR intervals in a } 24 \text {-hour continuous } \\
\text { electrocardiographic recording made } 11+/-3 \text { days after infarction was } \\
\text { significantly and strongly associated with subsequent mortality. }\end{array}$ & 1 & 1 & Finding \\
\hline
\end{tabular}

Note. Column II: Location of the sentence ( $\mathrm{A}=\mathrm{Abstract}, \mathrm{R}=$ Results, $\mathrm{D}=$ Discussion).

Column III: Sentence identified as main conclusion. Column IV: Number of students who mentioned this sentence as conclusion. Column V: Number of students who mentioned this sentence as main conclusion. Column VI: Rhetorical move of the sentence according to authors, following Dudley-Evans (1994). Reporting verbs and transition words/phrases are underlined. 
Table 3

Sentences identified as main conclusion by students $(n=20)$ in Article 3 .

\begin{tabular}{|c|c|c|c|c|c|}
\hline I & II & III & IV & $\mathrm{V}$ & VI \\
\hline $3 \mathrm{~A}$ & $\mathrm{D}$ & $\begin{array}{l}\text { These results show that chronic EPO treatment beginning } 7 \text { days after MI } \\
\text { reperfusion in rats attenuates cardiac remodeling and improves cardiac } \\
\text { function. }\end{array}$ & 18 & 15 & Conclusion \\
\hline $3 B$ & $\mathrm{D}$ & $\begin{array}{l}\text { These effects occurred only with an EPO dose that induced EPC mobilization } \\
\text { in blood and increased capillary density in the MI border zone. }{ }^{\dagger}\end{array}$ & 12 & 8 & Conclusion \\
\hline $3 C$ & $\mathrm{D}$ & $\begin{array}{l}\text { The improvement in cardiac contractility was clearly related to EPC } \\
\text { mobilization. }{ }^{\dagger}\end{array}$ & 8 & 4 & Conclusion \\
\hline $3 \mathrm{D}$ & $\mathrm{D}$ & $\begin{array}{l}\text { To our knowledge, this is the first study suggesting beneficial effects of } \\
\text { chronic EPO therapy at standard doses after I/R. }\end{array}$ & 4 & 2 & Conclusion \\
\hline $3 \mathrm{E}$ & A & $\begin{array}{l}\text { We found that chronic EPO treatment reduces MI size and improves cardiac } \\
\text { function only at a dose that induces EPC mobilization in blood and that } \\
\text { increases capillary density in the infarct border zone. }\end{array}$ & 2 & 2 & Conclusion \\
\hline $3 \mathrm{~F}$ & $\mathrm{R}$ & $\begin{array}{l}\text { No significant difference was observed between untreated MI rats and } \\
\text { infarcted rats receiving the lower dose of EPO. }\end{array}$ & 1 & 1 & Finding \\
\hline $3 \mathrm{G}$ & $\mathrm{R}$ & $\begin{array}{l}\text { In contrast, the higher dose of EPO prevented anterior wall thinning and LV } \\
\text { dilatation and preserved LV systolic function (Table 1). }\end{array}$ & 1 & 1 & $\begin{array}{l}\text { Statement } \\
\text { of result }\end{array}$ \\
\hline
\end{tabular}

Note. Column II: Location of the sentence (A=Abstract, $\mathrm{R}=$ Results, $\mathrm{D}=$ Discussion).

Column III: Sentence identified as main conclusion. Column IV: Number of students who mentioned this sentence as conclusion. Column V: Number of students who mentioned this sentence as main conclusion. Column VI: Rhetorical move of the sentence according to authors, following Dudley-Evans (1994). Reporting verbs and transition words/phrases are underlined.

${ }^{\dagger}$ Sentences identified as conclusion by Expert B. 
Table 4

Kinds of grounds identified by students $(n=17)$.

\begin{tabular}{lcc}
\hline & Assignment 2 & Assignment 3 \\
\hline Inscription & $49 \%$ & $39 \%$ \\
Statement of result & $18 \%$ & $27 \%$ \\
Finding & $15 \%$ & $12 \%$ \\
Conclusion & $5 \%$ & $9 \%$ \\
Citation & $23 \%$ & $26 \%$ \\
\hline
\end{tabular}

Note. In total, the students gave grounds for 109 (Assignment 2) and 74 (Assignment 3) text fragments. The percentages denote in how many instances students mentioned an inscription, statement of result, and so forth, as ground for their text fragments. 
Table 5

The grounds of three selected conclusions in Article 2 as given by 14 students.

\begin{tabular}{|c|c|c|c|c|c|c|c|c|}
\hline \multirow{2}{*}{$\begin{array}{l}\text { Sentences } \\
\text { identified } \\
\text { as } \\
\text { conclusion }\end{array}$} & \multirow[b]{2}{*}{$\begin{array}{l}\text { Number } \\
\text { of } \\
\text { students }\end{array}$} & \multicolumn{7}{|c|}{ Grounds } \\
\hline & & $\begin{array}{l}\text { Other } \\
\text { conclusion }\end{array}$ & Mortality & $\begin{array}{l}\text { Correlation } \\
\text { with other } \\
\text { variables }\end{array}$ & $\begin{array}{l}\text { Univariate/ } \\
\text { independent } \\
\text { relations }\end{array}$ & $\begin{array}{l}\text { Effects } \\
\text { of } \\
\text { drugs }\end{array}$ & $\begin{array}{l}\text { HRV \& } \\
\text { runs/ } \\
\text { couplets }\end{array}$ & Citation \\
\hline $2 \mathrm{H}$ & 8 & 0 & 5 & 1 & 2 & 1 & 0 & 3 \\
\hline $2 \mathrm{D}$ & 10 & 2 & 1 & 1 & 7 & 0 & 0 & 1 \\
\hline $2 \mathrm{E}$ & 7 & 1 & 0 & 0 & 1 & 0 & 5 & 1 \\
\hline
\end{tabular}

Note. Sentences can be found in Table 2. A grey cell indicates that the ground is incorrect according to the experts. 
Table 6

The grounds of three selected conclusions in Article 3 as given by 15 students.

\begin{tabular}{|c|c|c|c|c|c|c|c|c|c|}
\hline \multirow{2}{*}{$\begin{array}{l}\text { Sentences } \\
\text { identified } \\
\text { as } \\
\text { conclusion }\end{array}$} & \multirow{2}{*}{$\begin{array}{l}\text { Number } \\
\text { of } \\
\text { students }\end{array}$} & \multicolumn{8}{|l|}{ Grounds } \\
\hline & & $\begin{array}{l}\text { Other } \\
\text { conclusion }\end{array}$ & $\begin{array}{l}\text { Heart } \\
\text { function }\end{array}$ & $\begin{array}{l}\text { Infarct } \\
\text { size }\end{array}$ & $\begin{array}{l}\text { Cappilary } \\
\text { density }\end{array}$ & CD31 & Hematocrite & Apoptosis & Citation \\
\hline $3 \mathrm{~A}$ & 8 & 2 & 2 & 3 & 2 & 1 & 1 & 0 & 1 \\
\hline $3 B$ & 2 & & 1 & 1 & 2 & 0 & 0 & 0 & 0 \\
\hline $3 \mathrm{C}$ & 2 & & 0 & 0 & 1 & 1 & 0 & 0 & 0 \\
\hline $3 A+3 B$ & 3 & & 2 & 0 & 1 & 2 & 0 & 1 & 1 \\
\hline $3 A+3 B+3 C$ & 4 & 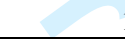 & 2 & 2 & 2 & 2 & 0 & 0 & 1 \\
\hline
\end{tabular}

Note. Sentences can be found in Table 3. A grey cell indicates that the ground is incorrect according to the experts. 


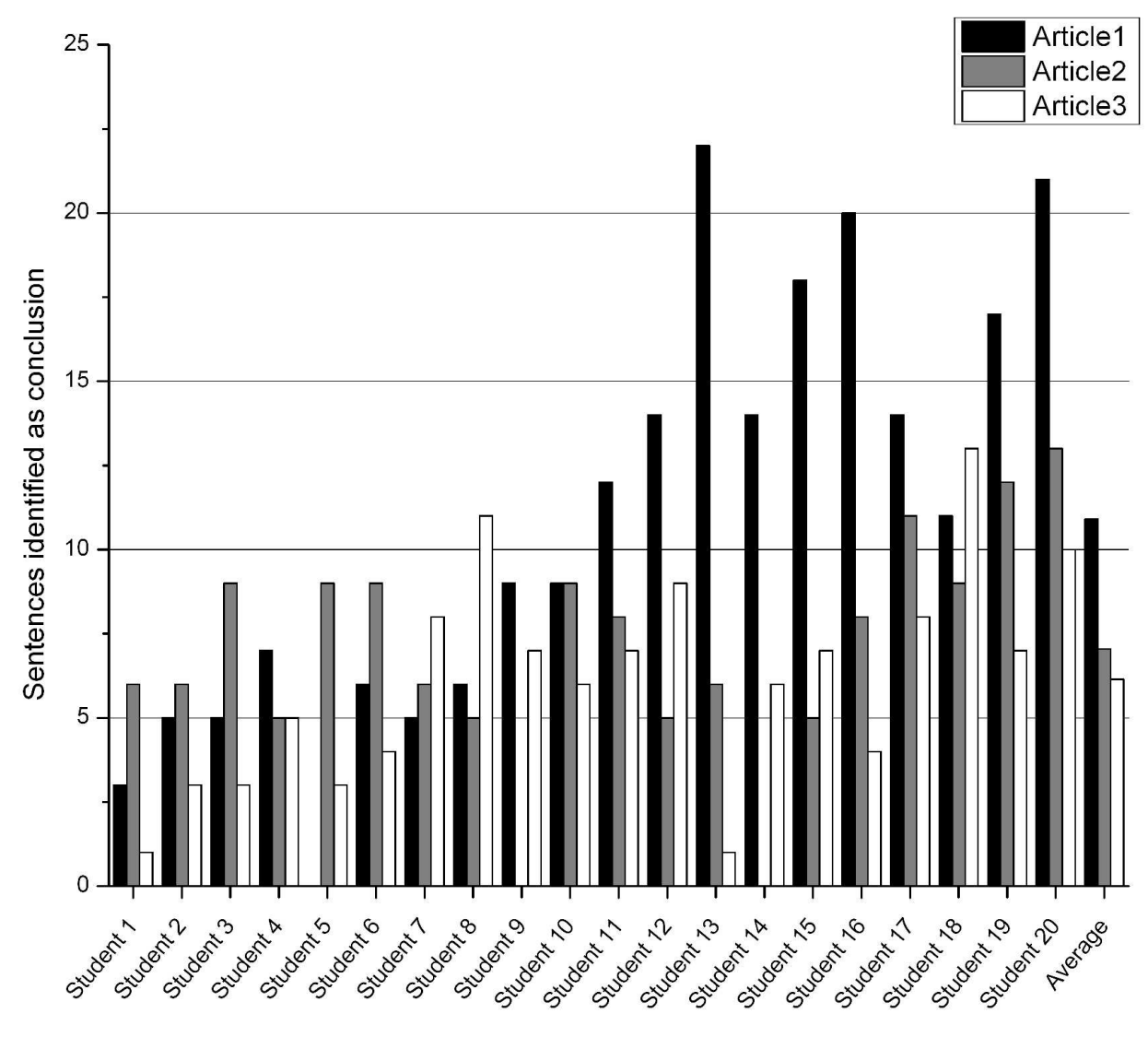

$304 \times 330 \mathrm{~mm}(300 \times 300$ DPI)

URL: http://mc.manuscriptcentral.com/tsed Email: editor_ijse@hotmail.co.uk 